\title{
The Meaning of Beauty in the Novel Laila and Maya by Ayu Utami
}

\author{
Wahyu Puspita Sari ${ }^{1(*)}$, Yasnur Asri ${ }^{1}$ \\ ${ }^{1}$ Universitas Negeri Padang, Indonesia \\ "Corresponding author.Email: wahyupuspitasr@gmail.com
}

\begin{abstract}
Meanings beauty usually makes everyone think, a woman with white skin, tall body, sharp nose and white teeth. Ayu Utami sees beauty in a different way from other people. Ayu Utami sees the beauty of deconstruction and difference (anomaly). This study aims to describe the meaning of beauty according to Ayu Utami who is different from other normal people. This type of research is qualitative research with descriptive methods. Qualitative research is research conducted looking at research subjects and presented descriptively in the form of words. The data in this study are words, phrases, sentences that contain elements of deconstruction or difference contained in the novel Laila and Maya by Ayu Utami. The data source in this research is novel Laila and Maya's by Ayu Utami. The research instrument was the researcher himself who was assisted with a data inventory table. Data collection methods and techniques used are by reading, recording what is included in a research study. After conducting the research, the researcher determines the shape of the meaning of beauty contained in the novel Laila and Maya by Ayu Utami.
\end{abstract}

\section{Keywords: Deconstruction, difference, novel (meaning of beauty)}

\section{INTRODUCTION}

The problem of beauty and views on the meaning of beauty attract many researchers' attention. Many researchers have reviewed the meaning of beauty. studied by several studies, but research generally only examines the meaning of beauty in general and does not examine other aspects of the meaning of beauty. Researchers who have conducted the research are, (1) Hayati (2012) examines the world of women in Indonesian women's literary works, (2) Siddik (2015) discusses the representation of women's beauty as a medium to attract men in the myth of marongge, (3) Julian (2016) examined the beauty myths in the short stories Dwi Ratih Ramadhany, (4) Fitrahayunitisna (2018) about the contradictions of beauty, metality, and the identity of women in the amba novel by Laksmi Pamunjak, (5) Saguni and Baharman (2016) examined the narratives about myths the beauty and body of women in contemporary Indonesian literature: the study of the works of Indonesian short-story writers.

The results of Siddik's research (2015) inform that women use pellets to lure men. Pellet is used by women to make her look beautiful and attractive. In the beginning, Mbah Gabuk used pellets because of the experience of his younger brother who had failed in romance. With this incident he did not want others to experience the same thing, that's why he made the science of pellets to conquer all men. In Siddik's research, it is clear that women use and use their beauty to attract men.
Based on relevant research, researchers only interpret the meaning of women's beauty umu. Women are said to be beautiful if they can be the center of attention, especially men. Women are said to be beautiful when they have a good body and attractive face. But Ayu Utami in her literary work makes a beautiful definition of something different. In general, the word beautiful is interpreted as a woman who is tall and slim, has white skin, sharp nose, curved fingers and neat teeth. Ayu Utami in her novel entitled Laiala and Lalita examines different things. He said women could also be said to be beautiful with different versions. The meaning of beauty made by Ayu Utami can be seen by using the theory of deconstruction and difference. The study in this study also uses the study of liberal feminism.

Literary works created by Ayu Utami are novels. The first concerning literary works, Ahadiat (2007) said that literary works are works of art that contain beauty. The beauty in a literary work is not only seen from the words, but also seen from the structure or completeness of a literary work. A beautiful literary work, not because the language is square and full of rhythm. It must be seen as a whole: its theme, its mandate, and its structure, as well as the values contained in the literary work. He also said if the literary work comes from the facts that live in society (objective reality). Atmazaki (2007) also said that literary works are artifacts or inanimate objects that come from reality that cannot do anything, so that reader activities are needed in reviving or interpreting them. 
One such work is novel. Tarigan (2011) said that the novel comes from the Latin word novellus which is derived from the word novies which means "new". Itsaid to be isnew because when compared to other types of literature such as poetry, drama, etc., this type of novel appears later. Kosasih (2012: 60) said the novel as a literary work in which tells the whole side of the problems of the life of a person or several people (figures). According to Luxemberg (in Ahadiat, 2007: 17) in our novel we not only understand the experience and inner life of fictional figures, but through these events we also gain an understanding of themes that are more general in nature, for example social themes, oppression in society, practices of corruption, love and sacrifice of a mother and others. In memkani beauty which is the problem formulation in this study, the elements that can be seen in the novel are characters and characterizations. Atmazaki (2007) said that a character is a person who is equipped with moral and character qualities, while characterization is how the author describes and develops the character's character in a prose. In line with that, Nurgiantoro (2010: 166) also said that the term characterization is broader because it also covers the problem of who the character is, how he characterizes, and how he is placed and illustrated in a story. From the expert's opinion, it can be concluded that characterization is a picture of a person's character in presenting each story in a work of fiction.

Feminism is also one thing that needs to be studied in studies that examine women. Feminism is a movement that ends the domination of men over women that has been happening in people's lives. Humm (2007: 157-158) said that feminism is combining the doctrine of feeling of rights for women who become organized movements to achieve women's human rights with an ideology of social transformation that aims to create a world for women. Moeliono et al (1993: 241) say that lexically feminism is a women's movement that guides the equal rights of men and women. The beginning of the birth of the feminism movement according to Segis Hastuti and Suharto, (2005: 61 ) because of the limitations of women from social, economic, and legal position as well as other things that make women always under the influence of men.

In interpreting the beauty contained in the novel Laila and Maya by Ayu Utami used the theory of decnstruction and difference. Darrida (1997) says deconstruction is a method used in reading a text (literature or philosophy). Deconstruction here is to interpret a text of a general meaning which is usually interpreted as a general meaning tomeaning

another. Other meanings obtained can be seen in logocentrism, fonosentrism, decentring. Logosentrisme is an idea or ideas that focus on everything that is logos. Fonosentrisme interpret the position of sound is very central. Fonosentrisme said if the presence of the narration is manifested as if it were present with sound rather than in writing.

Next is decentring or difference is a method of reading texts carefully so that the conceptual distinction of the authors' creations on which the text is based seems inconsistent and paradoxical in using concepts in the text as a whole (Zulfadhli, 2009: 132). Sarup (2008: 49) also says that a text fails to meet its own criteria, standards or definitions that the text constructs are used reflectively to shake and destroy the initial conceptual distinction of the tech. Difference can also be seen from three theories namely, paradoxicity, infinity and heteronotmativity.

\section{METHOD}

This research is a qualitative research with descriptive method. Qualitative research is research by looking at the subject of behavior, perception, motivation, action and others. Descriptive method is the translation with words or language (Moleong, 2010: 6). Descriptive method is done by collecting data, classifying data, and processing and interpreting data.

The data in this study are words, farsa, sentences that contain elements in interpreting beauty written by $\mathrm{Ayu}$ Utami in Laila and Maya novels. The data source in this research is Laila and Maya's novel by Ayu Utami. The research instrument was the researcher himself who was assisted with a data inventory table format, books and scientific articles related to research studies. Data collection techniques used are reading, identifying, classifying and inventorying data. The researcher first reads the novel Laila and Maya by Ayu Utami, then notes according to the indicators in the study.

The data analysis technique was carried out using descriptive techniques through content analysis. Content analysis has the characteristics of (1) the text must be processed according to the rules that have been designed, (2) the text is structured according to the specified categories, (3) the process of analyzing the theory must be based on the theory used, (4) the analysis process is in accordance with description, and (5) must use qualitative techniques and be implemented descriptively.

The data validation technique uses persistence techniques and triangulation techniques. Moleong (2010: 320) says the data validity testing technique is to increase the degree of data trust. Triangulation technique is a technique that utilizes something outside the data for data checking purposes.

\section{RESULTS AND DISCUSSION}

Based on background analysis of Laila and Maya's novel by Ayu Utami, which tells about humans (women) with a different background from other normal humans. Laila's novel tells the story of a woman who is considered strange by Yuda's figure, where Laila who is outrageous appears with her makeup and make-up that doesn't seem like anyone else wants to know how cool she is. Maya's novel tells how totok-biased characters are said to have an abnormal life like or should be done by normal people.

Ayu Utami revealed the other sides of the word beautiful which are generally white, tall and white-faced women. Ayu Utami revealed how people who could be said to be "abnormal" lived life as those who were said to be normal.

In the hallway between the rows of tables there appeared the figure, swinging tiptoeing steps — the cat led 
them. The model mimics the animal on the catwalk. A cat wearing a bell to be recognized. And this figure ... his body is very slim, if not thin. The neck belt is flickering. He wore a purple tanktop in contrast to his yellow skin and tight jeans. From underneath the jeans Iyu poked his feet on tiptoe in his shoes with pointed heels. Her nails were painted blood red at night. The fingers are long and curved. Perfect like a fairy who has never stepped on the ground. His right ankle was attached to a white gold bracelet with small bells. Genta berenting accompanies his steps. Her hair is like silk threads ironed and curled at the ends. From a distance his eyes looked very alive. However, the closer it seems that the woman's eyelids with dark colors are very dark. Dark is not plural. (Utami, 2012: 8)

In the first data, Ayu Utami revealed in the novel Lalita that she explained that beautiful is the perfect woman. Perfect means that here is thin body, curved nails, leveled legs with highils, smooth and wavy hair. The beauty of the figure is described by Ayu Utami as if a fairy descended to earth. Ayu Utami gives the reader the idea that the character is very beautiful with a perfect body and coupled with makeup and clothes that are also very good.

The skin is really olive and smooth. Her hair is as thick as a palm but soft as satin, so inviting to hold. Pointed nose. All teeth are stored neatly inside the lips: none of them are sticking out. His arms, which are now learning to bulldoze a chicken, hold their legs very slender and perfect, the legs are so long that even if they are attached, they are still long from the dwarf's legs. Like pandopo poles that are knotted so smooth and oiled that your palm must be happy to rub and nose, u want to sniff (Utami, 2013: 69) The

data above, Ayu Utami also explains the same beauty as the meaning of beauty in general. The meaning of beautiful means that has thick hair like fibers but soft like satin, sharp nose, neat teeth, and also long legs. Ayu Utami here explains if the beautiful boundaries in the Maya novel, beautiful women are women who have long legs (women with average height of Indonesian women). In the above quote, Ayu Utami revealed the beautiful boundaries that develop in society, especially Indonesia. In other words, women who fall within these limits are included in normal humans who can be said to be beautiful. So beautiful women can be interpreted as normal women.

In this section Ayu Utami describes the binary opposition between beautiful and ugly, beautiful and bad, or normal and abnormal. Maya's novel begins with a depiction of the main character, Yasmin, who travels to a spiritual hermitage belonging to Suhubudi. One of the drawings by Ayu Utami is a dancer from the Ramayana ballet.

It appears that creatures that have never appeared during the day as normal humans. Deformation creatures. Almost all have short legs, straight or curved. Except for the big figures who play as giants. Their faces are not mature, but there are at odd ages that bring together childhood and deity at the same time. The faces of the edge of age, when humans just begin to live or almost end it. The prince Rahwana is a big man with scaly skin. Rama will tell you about the tuyul. And Sita. The touching seizure was an albino dwarf woman. His eyes narrowed and his mouth grimaced. How thin hair. (Utami, 2013: 33)

In the Ramayana story, the story is identical to Sita's beauty and Rama's good looks. In the Maya novel, Ayu Utami tells with different circumstances anyway. The figure is actually displayed by dancers with physical conditions that are contrary to the Ramayana dancers in general. In general, Indonesia, especially Java, presents dancers in a beautiful, beautiful, elegant and beautiful body. In the novel, Ayu Utami is just the shadow of the panarians, so outwit the audience because the picture of the original dancer looks different. In other words, not showing the original dancer as if showing that such physical physical conditions are not appropriate to be shown directly. The physical condition of the dancers is not included in the category of Ramayana dancers that are often understood by people in general, for that they must be hidden.

The data above shows when the sandratari performance event has finished and the performance screen opens. There was a surprise from the audience when they found out and saw the dancer and the main character in the event. The novel excerpt above interprets human condition which is considered abnormal. Evidenced by the appearance of creatures that never appeared during the day as a normal human being. The figure is narrated as a human who never appears because it is not natural like other normal humans. that is, these humans are abnormal, unnatural and different from the others.

There Suhubudi maintained an army of strange humans, if not disabled humans. The warriors were called the Saduki Clan, who knows what that meant. This group contains people who are usually thrown away by the community, or used to beg. But no, the occupants of the stern complex were not pregnant or crippled-legged humans. They are figures who are too frightening so the brokers don't want to employ them as beggars. (Utami, 2013: 43) The data above illustrates how Suhubudi "took care" of people who were discarded from the community. People who are generally said to be disabled, are grouped into a community. With this grouping, they are marginalized and included in the "other" category. The description above clearly illustrates how people with disabilities are considered abnormal people. The explanation is also emphasized in the data (Utami, 2013: 43) "You will find women with bubbly skin, human lizards, elephantiasis creatures, men with fingers like mangrove roots, in addition to midget troops".

From some of the data above explains about the physical depictions that have an abnormal person, that is physically bad and disabled. Physical depictions were repeated several times by Ayu Utami. This repetition is used to emphasize abnormal forms in society. The portrayal of the dancers is considered abnormal, reinforced by the assumption that they have physical characteristics such as spirits or animals. Another word used to describe these abnormalities is that they have eyes that are not symmetrical. 
Ayu Utami in her two novels (Laila and Maya) interpret beauty from a different perspective. Ayu Utami makes a beautiful meaning from what the community can say is not normal.

\section{CONCLUSION}

Maya and Lalita novels are novels that offer criticism of beauty, especially on the side of what is normal and not normal. This explains how abnormal people can do what normal people do. However, the point here is women's beauty. In the novel Lalita, a character named Lalita wears a variety of decorations that make her look beautiful. In the Maya novel, Maya characters who have flaws (physical disabilities such as skin color, hair, teeth and height) can do what normal people do. Maya is a dancer in the Ramayana story where she usually presents a beautiful Sinta figure, but Maya is able to become a beautiful Sinta who is beautiful even though only by showing her shadow. Actual beauty like Maya is not needed when he dances in the shadow because what is present is never presented by the people of Maya. Beauty is only a blur that does not have a complete presentation in its totality. For Maya, beauty is the imperfection or the badness and this is what krik Ayu Utami through her novel.

\section{REFERENCES}

[1] Ahadiat, Endut. 2007. Teori dan Apresiasi kesusastraan. Padang: Bung Hatta University Press.

[2] Atmazaki. 2007. Ilmu Sastra: Teori dan Terapan. Padang: UNP Pres.

[3] Derrida, Jacques. 1973. Speech and Phenomena, and Other Essays on Husserl's Theory of Signs (terj. David B. Allison dan Newton Garver). Evanston: Northwestern University Press

[4] Derrida, Jacques. 1981a. Dissemination (terj. Barbara Johnson). London: Athlone Press.

[5] Derrida, Jacques. 1981b. Positions (terj. Alan Bass). Chicago: The University of Chicago Press.

[6] Derrida, Jacques. 1982. Margins of Philosophy (terj. Alan Bass). Chicago: The University of Chicago Press.

[7] Derrida, Jacques. 1997. Of Grammatology (terj. Gayatri Chakravorty Spivak). Baltimore: The Johns Hopkins University Press.

[8] Fitrahayunitisna. 2018. Kontradiksi Kecantikan, Mentalitas, dan Identitas Perempuan Dalam Novel Amba Karya Laksmi Pamntjak. Jurnal Pendidikan Bahasa Dan Sastra Indonesia. Vol. 01, No. 04.

[9] Hayati, Yenni. 2012. Dunia Perempuan Dalam Karya Sastra Perempuan Indonesia (Kajian Feminisme). Jurnal Humanus. Vol. XI No.1.

[10]Julian, Royyan. 2016. Mitos Kecantikan Dalam Cerpen-Cerpen Dwi Ratih Ramadhany. Jurnal poetika. Vol. IV No.1.

[11] Kosasih, E. 2012. Dasar-Dasar Keterampilan Bersastra. Bandung: Yrama Widya.
[12] Moleong, Lexy J. 2010. Metode Penelitian Kualitatif. Bandung: Remadja Rosdakarya.

[13] Saguni, Suarni Syam dan Baharman. 2019. Narasi tentang Mitos Kecantikan dan Tubuh Perempuan Dalam Sastra Indonesia Mutakhir: Studi Atas Karya-Karya cerpenis Indonesia. Jurnal Retorika. Vol. 9 No.2.

[14] Sarup, Madan. 2008. Panduan Pengangtar Untuk Memahami Postrukturalisme dan Posmodernisme (Terjemahan Medky Aginta Hidayat). Yogyakarta: Jalasutra.

[15] Siddik, Burhan. 2015. Representasi Kecantikan Perempuan Sebagai Media Pemikat Laki-laki Dalam Mitos Marongge. Jurnal Riksa Bahasa. Vol. 1 No. 2.

[16] Tarigan, Henry Guntur. 2011. Prinsip-Prinsip Dasar Sastra. Bandung: Angkasa.

[17] Utami, Ayu. 2012. Lalita. Jakarta. PT Gramedia.

[18] Utami, Ayu. 2013. Maya. Jakarta. PT Gramedia.

[19]Zulfadhli. 2009. Dekonstruksi Dalam Cerpen Malin Kundang, Ibunya Durhaka Karya A.A Navis. Jurnal Bahasa dan Seni. Vol 10 No 2. 